\title{
PENINGKATAN KREATIVITAS DAN HASIL BELAJAR MATEMATIKA MELALUI MODEL PEMBELAJARAN KOOPERATIF TIPE-STAD TERINTEGRASI ICT
}

\author{
Rizki Kurniawan Rangkuti ${ }^{1}$, Marwan Ramli ${ }^{2}$, Mulkan Iskandar Nasution ${ }^{3}$ \\ ${ }^{1}$ Universitas Al-Washliyah Labuhanbatu, Jalan H. Adam Malik Lingkar By Pass, Rantauprapat 21421, Indonesia \\ ${ }^{2}$ Universitas Syiah Kuala, Jalan Syeikh Abdur Rauf, No.4, Banda Aceh 23111, Indonesia \\ ${ }^{3}$ Universitas Islam Negeri Sumatera Utara, Jalan Williem Iskandar, Medan 20371, Indonesia \\ Email: rizkikurniawanrangkuti@gmail.com \\ Email: marwan.math@unsyiah.ac.id \\ Email: almana@gmail.com
}

\begin{abstract}
Abstrak
Penelitian ini dilatarbelakangi oleh rendahnya kemampuan siswa dalam mengerjakan soal matematika, hal ini disebabkan rendahnya kreativitas siswa dalam belajar matematika, oleh karena itu dalam penelitian ini kreativitas dibangun dengan model pembelajaran kooperatif tipe-STAD terintegrasi ICT. Jenis penelitian ini adalah penelitian tindakan kelas. Sebelum tindakan dilakukan terlebih dahulu diberikan tes awal. Dari hasil tes awal yang diperoleh rata-rata pencapaian siswa 20,62 dengan tingkat ketuntasan klasikal 0\%. Setelah pemberian tindakan I untuk tes berpikir kreatif tingkat ketuntasan belajar siswa secara klasikal adalah 15\%, dengan ratarata pencapaian kelas 33,75. Untuk tes hasil belajar siswa tingkat ketuntasan yang diperoleh siswa adalah $17,5 \%$, dengan rata-rata pencapaian kelas 26,42. Setelah pelaksanaan tindakan II untuk tes berpikir kreatif tingkat ketuntasan belajar siswa secara klasikal adalah $85 \%$, dengan rata-rata pencapaian kelas 72,85 . Untuk tes hasil belajar siswa tingkat ketuntasan yang diperoleh siswa adalah 90\%, dengan rata-rata pencapaian kelas 77,17. Dari hal tersebut ada peningkatan tingkat ketuntasan klasikal sebesar $70 \%$ untuk berpikir kreatif siswa dan $72,5 \%$ untuk hasil belajar matematika siswa.
\end{abstract}

Kata Kunci: Kreativitas Matematika, Hasil Belajar Matematika, Model Pembelajaran Kooperatif TipeSTAD, Media ICT

\begin{abstract}
This research was conducted for 2 weeks in October at SMAN 11 Medan. This type of research is classroom action research. Before the action is taken first, the initial test is given. From the results of the initial test, the average student achievement was 20.62 with a classical completeness level of $0 \%$. After giving action I to creative thinking tests the level of student study in classical is $15 \%$, with an average grade achievement of 33.75. To test student learning outcomes the level of completeness obtained by students is $17.5 \%$, with an average grade achievement of 26.42. After the implementation of action II for creative thinking tests the level of student study learning in classical is $85 \%$, with an average achievement of 72.85 classes. To test student learning outcomes the level of completeness obtained by students is $90 \%$, with an average grade achievement of 77.17. From this there is an increase in the level of classical completeness by $70 \%$ for students 'creative thinking and $72.5 \%$ for students' mathematics learning outcomes.
\end{abstract}

Keywords: Mathematical Creativity, Mathematics Learning Outcomes, Cooperative Type-STAD Learning Model, ICT Model

\section{PENDAHULUAN}

Dunia pendidikan adalah harapan bangsa dan negara sesuai dengan tujuan pendidikan nasional yaitu mencerdaskan kehidupan bangsa dan negara. Pendidikan yang menuntut kepada pola pikir salah satunya adalah pendidikan matematika sebagai salah satu bidang studi yang diajarkan di setiap 
jenjang pendidikan. Dalam proses pembelajaran matematika terdapat beberapa faktor yang menyebabkan rendahnya prestasi belajar siswa, berdasarkan hasil observasi di kelas penelitian ditemukan tidak adanya media pembelajaran yang dapat mendukung kegiatan mengajar guru dan model pembelajaran yang diterapkan guru tidak efektif dalam membangun kreativitas sehingga berakibat hasil belajar yang tidak optimal. Oleh karena itu diperlukan suatu model dan media pembelajaran yang dapat membuat peserta didik tertarik dalam pembelajaran matematika.

Saat peneliti melakukan observasi sebelum penelitian dilakukan di kelas $X_{6}$ SMA Negeri 11 Medan tepatnya 16 Juli 2012 terdapat beberapa informasi yang mencerminkan keadaan siswa selama proses pembelajaran, diantaranya adalah :

1. Sebagian siswa terlihat tidak terbiasa dalam belajar matematika, menurut peneliti mungkin siswa tersebut kurang diberi PR matematika oleh guru bidang studi;

2. Siswa terlihat kurang memiliki keterampilan dalam mengerjakan soal, mungkin dikarenakan tidak terbiasa dalam mengerjakan soal, sehingga kreativitas yang dimiliki siswa kurang berproduksi;

3. Siswa laki-laki terlihat kurang memiliki kemauan untuk belajar matematika dari pada siswa perempuan, hal ini mungkin dikarenakan model pembelajaran yang diberikan tidak model pembelajaran kooperatif (pembelajaran berkelompok) yang disertai dengan media pembelajaran yang mendukung.

Menurut Kagan (Hosnan, 2014:235) pembelajaran kooperatif adalah strategi pengajaran yang sukses di mana tim kecil masing-masing dengan siswa dari tingkat kemampuan yang berbeda menggunakan berbagai aktivitas belajar untuk meningkatkan pemahaman mereka tentang suatu subjek. Dengan pandangan tersebut, maka pembelajaran matematika dengan menggunakan pembelajaran kooperatif memungkinkan siswa dapat menguasai konsep matematika dengan baik melalui fakta-fakta yang sifatnya kontekstual. Salah satu model pembelajaran yang mengakomodir semua tingkatan sosial murid adalah model pembelajaran kooperatif tipe-STAD. Di dalam pembelajaran tersebut seluruh siswa dibagi dalam kelompok-kelompok kecil dengan mempertimbangkan heterogenitas anggota di dalamnya. Hal ini sesuai dengan pendapat Slavin (Trianto, 2012:68) yang menyatakan bahwa pada STAD siswa ditempatkan dalam tim belajar beranggotakan 4-5 orang yang merupakan campuran menurut tingkat prestasi, jenis kelamin, dan suku. Dalam hal ini siswa yang tingkatan kognitifnya rendah dapat belajar dengan siswa yang tingkat kognitifnya sedang dan tinggi, kemudian satu siswa dengan siswa lainnya dalam satu kelompok dapat mengenal lebih karakter mereka terlebih dalam belajar.

Dalam suatu proses belajar mengajar, media pembelajaran memiliki peranan yang sangat penting karena salah satu fungsi utama media pembelajaran adalah sebagai alat bantu mengajar yang turut mempengaruhi iklim, kondisis dan lingkungan belajar yang ditata dan diciptakan oleh tenaga pendidik. Hal ini sesuai dengan pendapat Hamalik (Edi, 2011:16) mengemukakan bahwa pemakaian media pembelajaran dalam proses pembelajaran dapat membangkitkan keinginan dan minat yang 
baru, membangkitkan motivasi dan rangsangan kegiatan belajar dan bahkan membawa pengaruh psikologis terhadap siswa. Salah satu media pembelajaran yang memiliki fungsi kognitif dan afektif adalah media pembelajaran berbasis ICT, karena berdasarkan beberapa temuan penelitian yang mengungkapkan bahwa lambang visual atau gambar memperlancar pencapaian tujuan untuk memahami informasi dan tingkat kenikmatan peserta didik ketika belajar atau membaca teks yang terkandung dalam gambar. Gambar atau lambang visual dapat menggugah emosi dan sikap siswa, misalnya informasi yang menyangkut masalah sosial atau ras. Dengan kenikmatan peserta didik ketika belajar untuk memahami informasi yang terkandung dalam gambar akan meningkatkan kelancaran, keluwesan dan originalitas siswa dalam menyelesaikan soal matematika. Dalam hal ini Guilford dan Torrence (Pardede, 2010:19) menyatakan bahwa kekuatan dasar kreativitas meliputi aspek kelancaran, keluwesan dan originalitas, atau disebut juga sebagai indikator kemampuan berpikir kreatif.

\section{METODE PENELITIAN}

Jenis penelitian ini adalah penelitian tindakan kelas (Classroom Action Research). Penelitian ini dilaksanakan selama 2 minggu pada semester ganjil tepatnya bulan Oktober tahun ajaran 2012-2013. Penelitian ini dilaksanakan di SMA Negeri 11 Medan Jalan Pertiwi Medan Tembung. Adapun objek penelitian ini adalah bagaimana meningkatkan kreativitas dalam rangka peningkatan hasil belajar siswa melalui media pembelajaran berbasis ICT dengan model pembelajaran kooperatif tipe STAD pada pokok bahasan fungsi kuadrat di kelas X SMA Negeri 11 Medan. Subjek penelitian ini adalah siswa kelas $\mathrm{X}_{6}$ SMA Negeri 11 Medan tahun ajaran 2012-2013 yang berjumlah 40 siswa. Alat yang digunakan untuk mengumpul data dalam penelitian ini adalah wawancara, observasi dan tes yang hasilnya akan dipaparkan pada hasil penelitian.

\section{HASIL PENELITIAN DAN PEMBAHASAN}

Berdasarkan hasil observasi kreativitas siswa diperoleh beberapa informasi, yaitu :

1. Rasa ingin tahu siswa kurang, hal ini dapat dilihat dari kurangnya siswa dalam mengajukan pertanyaan;

2. Kurangnya kemauan siswa dalam memberikan tanggapan untuk membuat suatu kesimpulan sendiri;

3. Rendahnya partisipasi siswa memberi respon terhadap siswa lain;

4. Tidak terlihatnya kesadaran siswa dalam mencari alternatif pemecahan untuk menyelesaikan masalah yang sama;

5. Siswa mudah terpengaruh terhadp pendapat otoritas.

Dari hasil observasi di atas maka dapat disimpulkan bahwa kreativitas siswa kurang. 
Selanjutnya dilakukan wawancara kepada siswa yang mengalami kesulitan belajar seiring tes berpikir kretif I dilaksanakan. Dari hasil wawancara kepada 6 orang siswa pada siklus I diperoleh bahwa kesulitan yang dialami siswa sebagai berikut :

1. Kurangnya pemahaman siswa dalam menentukan beberapa koordinat titik sedemikian sehingga apabila diberikan sebarang titik-titik akan diketahui apakah titik-titik tersebut terdapat pada parabola atau tidak;

2. Kurangnya pemahaman siswa dalam menggambar grafik fungsi $f(x)$.

Berdasarkan hasil jawaban siswa yang diberikan pada tes kemampuan berpikir kreatif pada siklus I dideskripsikan tingkat berpikir kreatif siswa sebagai berikut:

1. Dilihat dari kemampuan siswa dalam berpikir kreatif lancar bahwa tidak ada yang memiliki kemampuan tinggi dari 40 orang siswa dan juga tidak ada yang memiliki kemampuan sedang dari 40 orang siswa yang memiliki kemampuan tinggi maupun sedang. Sementara terdapat 40 orang siswa yang memiliki kemampuan rendah dengan rata-rata kemampuan siswa dalam berpikir lancar 5,12.

2. Dilihat dari kemampuan siswa dalam berpikir luwes terdapat 6 orang siswa dari 40 orang siswa yang memiliki kemampuan tinggi, 2 orang siswa yang memiliki kemampuan sedang, dan 32 orang siswa yang memiliki kemampuan rendah dengan rata-rata kemampuan siswa dalam berpikir luwes 35,62.

3. Dilihat dari kemampuan siswa dalam berpikir original terdapat 4 orang siswa dari 40 orang siswa yang memiliki kemampuan tinggi, 7 orang siswa dari 40 orang siswa yang memiliki kemampuan sedang, dan 29 orang siswa yang memiliki kemampuan rendah dengan rata-rata kemampuan siswa dalam berpikir original 35,62.

Dari hasil tes berpikir kreatif siswa I yang diberikan kepada 40 orang siswa diperoleh 34 orang siswa yang belum mencapai skor lebih besar dari 60, 6 orang siswa yang mencapai skor lebih besar dari 60 dengan rata-rata skor berpikir kreatif siswa 33,75. Dari hasil tes belajar I, diperoleh bahwa penguasaan siswa terhadap materi fungsi kuadrat sangat rendah. Pada materi fungsi kuadrat dari 40 orang siswa terdapat 7 orang siswa telah mencapai ketuntasan belajar, sedangkan 33 orang siswa belum mencapai ketuntasan belajar. Nilai rata-rata kelas yang diperoleh pada tes hasil belajar I ini yaitu 26,42. Sebagai refleksi kemampuan berpikir kreatif I pada pembelajaran pada siklus I, diperoleh 6 orang siswa yang lulus KKM (skor lebih besar dari 60) berarti belum tercapai ketuntasan berpikir kreatif secara klasikal. Begitu juga refleksi hasil belajar pada siklus I, hanya diperoleh 7 orang siswa yang lulus KKM (skor lebih besar dari 60) berarti belum tercapai ketuntasan hasil belajar secara klasikal. Dengan belum tercapainya tingkat ketuntasan secara klasikal kemampuan berpikir kreatif dan hasil belajar sehingga perlu dilanjutkan ke siklus II dengan memperbaiki kegagalan dan meningkatkan keberhasilan yang telah tercapai pada siklus I. 
Hasil observasi kreativitas siswa pada siklus II mengalami peningkatan dari hasil observasi kreativitas siswa pada siklus I dengan tingkat kreativitas siswa dalam kegiatan pembelajaran berada pada kategori baik. Dari wawancara pada siklus II diperoleh informasi bahwa terdapat beberapa orang siswa yang masih mengalami kesulitan dalam menyelesaikan soal yang menuntut kreativitas dalam berpikir.

Berdasarkan hasil jawaban siswa yang diberikan pada tes berpikir kreatif II pada siklus II dideskripsikan tingkat kemampuan berpikir kreatif II siswa sebagai berikut :

1. Dilihat dari kemampuan siswa dalam berpikir lancar terdapat 28 orang siswa dari 40 orang siswa yang memiliki kemampuan tinggi, tidak ada seorang siswa yang memiliki kemampuan sedang, dan terdapat 12 orang siswa dari 40 orang siswa yang memiliki kemampuan rendah dengan nilai rata-rata kemampuan siswa dalam berpikir lancar adalah 71,55.

2. Dilihat dari kemampuan siswa dalam berpikir luwes terdapat 29 orang siswa dari 40 orang siswa yang memliki kemampuan tinggi, 4 orang siswa dari 40 orang siswa yang memiliki kemampuan sedang, dan 7 orang siswa dari orang 40 siswa yang memiliki kemampuan rendah dengan nilai rata-rata kemampuan siswa dalam berpikir luwes adalah 79,08.

3. Dilihat dari kemampuan siswa dalam berpikir original terdapat 25 orang siswa dari 40 orang siswa yang memiliki kemampuan tinggi, 1 orang siswa dari 40 orang siswa yang memiliki kemampuan sedang, dan 14 orang siswa dari 40 orang siswa yang memiliki kemampuan rendah dengan nilai rata-rata kemampuan siswa dalam berpikir original adalah 66,75.

Dari hasil tes berpikir kreatif II yang diberikan kepada 40 orang siswa diperoleh 34 orang siswa yang mencapai skor lebih besar dari 60, dan terdapat 6 orang siswa yang belum mencapai skor lebih besar dari 60 dengan skor rata-rata berpikir kreatif II adalah 72,85. Dari tes hasil belajar II, diperoleh bahwa penguasan siswa terhadap materi fungsi kuadrat sudah meningkat dari siklus I ke siklus II. Pada materi fungsi kuadrat dari 40 orang siswa terdapat 36 orang siswa telah mencapai ketuntasan belajar, sedangkan 4 orang siswa belum mencapai ketuntasan belajar. Nilai rata-rata kelas yang diperoleh pada tes hasil belajar II adalah 77,17. Hal ini menunjukkan bahwa kemampuan siswa pada tes hasil belajar II meningkat sebesar 50,75 dari tes hasil belajar I.

Sebagai refleksi kemampuan berpikir kreatif II pada pembelajaran pada siklus II, diperoleh 34 orang siswa yang lulus KKM (skor lebih besar dari 60) dalam hal ini ketuntasan berpikir kreatif secara klasikal sebesar 85\%, hal ini berarti ketuntasan berpikir kreatif secara klasikal tercapai. Refleksi hasil belajar pada siklus II, diperoleh 36 orang siswa yang lulus KKM (skor lebih besar dari 60) dalam hal ini ketuntasan hasil belajar secara klasikal sebesar 90\%. Dengan belum tercapainya tingkat ketuntasan secara klasikal kemampuan berpikir kreatif dan hasil belajar sehingga perlu dilanjutkan ke siklus II dengan memperbaiki kegagalan dan meningkatkan keberhasilan yang telah tercapai pada siklus I. 


\section{KESIMPULAN}

Berdasarkan hasil penelitian yang disajikan, maka dapat diambil kesimpulan bahwa :

1. Berdasarkan hasil penelitian diperoleh bahwa melalui media pembelajaran berbasis ICT dengan model pembelajaran kooperatif tipe STAD dapat meningkatkan kreativitas siswa pada pokok bahasan fungsi kuadrat di kelas $\mathrm{X}_{6}$ SMA Negeri 11 Medan tahun ajaran 2012-2013.

2. Berdasarkan hasil penelitian diperoleh bahwa melalui media pembelajaran berbasis ICT dengan model pembelajaran kooperatif tipe STAD dapat meningkatkan hasil belajar matematika siswa pada pokok bahasan fungsi kuadrat di kelas $\mathrm{X}_{6}$ SMA Negeri 11 Medan tahun ajaran 2012-2013.

\section{REFERENCES}

Edi, Sarwo. (2011). Penerapan Media Software Autograph Untuk Meningkatkan Pemahaman Matematika Siswa Pada Pokok Bahasan Persamaan Garis Lurus Di Kelas VIII SMP Swasta Islam Terpadu Darul Azhar Aceh Tenggara Tahun Ajaran 2010-2011. Unpublished Skripsi. Medan: State University of Medan.

Hosnan, M. (2014). Pendekatan Saintifik dan Kontekstual dalam Pembelajaran Abad 21; Kunci Sukses Implementasi Kurikulum 2013, Bogor: Ghalia Indonesia.

Pardede, Herfina. (2010). Penerapan Pembelajaran Kooperatif Tipe-STAD Untuk Meningkatkan Kreativitas dan Hasil Belajar Matematika Siswa Pada Pokok Bahasan Bangun Datar di Kelas VII SMP Negeri 10 Medan Tahun Ajaran 2009-2010. Unpublished Skripsi. Medan: State University of Medan.

Trianto. (2012). Mendesain Model Pembelajaran Inovatif-Progresif, Jakarta: Krismatik. 